\title{
“Nabucco" by Giuseppe Verdi: A Case of Delirium in an Italian Romantic Opera
}

\author{
Luca Cambioli Mattia Bava Giuseppe Bellelli Massimo Clerici \\ Giancarlo Cesana Michele Augusto Riva
}

School of Medicine and Surgery, University of Milano Bicocca, Monza, Italy

\author{
Keywords \\ Delirium · Opera · Music · Giuseppe Verdi . \\ Nabucco $\cdot$ History
}

\begin{abstract}
Italian operas can provide relevant information on the medical knowledge during the Romantic Age, especially in the field of neuroscience. One of the most renowned operas, "Nabucco" by Giuseppe Verdi (1813-1901) may provide us with some information on the state of knowledge on neuropsychiatric diseases in the first part of the nineteenth century. The main character of this opera, the Assyrian king Nabucco suffers from delirium. Psychic signs and symptoms attributed to Nabucco in Verdi's opera could have been influenced by a better knowledge of neuropsychiatric diseases in the nineteenth century. Furthermore, the representation of Nabucco's mental illness in the opera could also have been influenced by direct experiences of Verdi himself, who seems to have suffered from recurrent depressive episodes in that period, and for the rest of his life.

(C) 2017 S. Karger AG, Basel
\end{abstract}

\section{Introduction}

Romantic operas, as an expression of the nineteenth century, can provide relevant information on the medical knowledge during that period, especially in the field of neuroscience [1-4]. One of the most renowned operas from those years is "Nabucco" by Giuseppe Verdi (18131901), considered by several scholars to be a symbol of the Italian Risorgimento; the political and social movement for the unification of Italy into a single state. The famous "Va, pensiero" chorus sung in Act Three by the Hebrew slaves was indeed looked upon as a national anthem by the Italians. It was, therefore, forbidden by the Austrian authorities ruling northern Italy at the time, to prevent public protests and riots. In addition to its political contents, Nabucco, composed in 1841 and premiered at the Teatro La Scala in Milan in the following year, may provide us with some information on the state of knowledge on neuropsychiatric diseases in the first part of the nineteenth century.

Its libretto, based on the events described in the Bible Books of Daniel and Jeremiah, was written by Temistocle Solera (1815-1878), and inspired by the drama "Nabuchodonosor" (1836) by Auguste Anicet-Bourgeois and Francis Cornue. The plot, divided in 4 acts, develops around the conquest of Jerusalem by the Babylonian king Nebuchadnezzar II - named as Nabucco in the opera - and the attempt of his daughter Abigaille to usurp the throne. When, at the end of Act Two, Nabucco declares not to be king anymore but a divinity, he is suddenly struck on the head by a bolt of lightning, seemingly thrown by God. This causes the conqueror to faint and subsequently be in a state of altered mental functions. Such a condition appears to be transitory, since
KARGER

(C) 2017 S. Karger AG, Basel

E-Mail karger@karger.com

www.karger.com/ene
Michele Augusto Riva, MD, PhD

School of Medicine and Surgery

University of Milano Bicocca

via Cadore 48, IT-20900 Monza (Italy)

E-Mail michele.riva@ unimib.it 
Nabucco recovers his senses in the fourth act. This episode of temporary insanity - which Nabucco suffers from in the opera - seems to be different from the original biblical description. Indeed, the book of Daniel depicted King Nebuchadnezzar losing his mental sanity and living in the wild like an animal for a long period of time (7 years) [5]. Psychic signs and symptoms attributed to Nabucco in Verdi's opera could have been influenced by a better knowledge of neuropsychiatric diseases in the nineteenth century. Furthermore, the representation of Nabucco's mental illness in the opera could have also been influenced by direct experiences of the Italian composer himself, who seems to have suffered from recurrent depressive episodes in that period, and for the rest of his life.

\section{Delirium in Verdi's “Nabucco"}

The opera is initially set in the Temple of Solomon in Jerusalem: Nabucco, King of Babylon, has attacked the Israelites with his hordes and is desecrating the city. During his first appearance (Act One, scene 7), when Nabucco enters the Temple, he appears to be awake, aware, alert and oriented in both space and time. No signs or symptoms of mental illness can be evidenced. He may sound conceited or even megalomaniac, but it is compatible with his social role of king. With blasphemous arrogance, Nabucco orders the Temple to be looted and burned, and the Israelites forcibly deported to Babylon. In the Second Act, set in the royal palace in Babylon, the Assyrian High Priest of Bel is organizing a plot to overthrow the king and replace him with his daughter, Abigaille. For this reason, he has spread the rumor that Nabucco has died in the battle. To the astonishment of all, when Abigaille is proclaimed ruler, Nabucco enters, takes the crown and places it on his own head. During scene 8 , in a manic escalation, Nabucco declares he has overthrown both the Babylonian and Israelites' God:

S'oda or me!... Babilonesi, getto a terra il vostro dio! Traditori egli v'ha resi, volle torvi al poter mio; cadde il vostro, o stolti Ebrei, combattendo contro me, ascoltate i detti miei...V'è un sol Nume... il vostro Re!

(Hear me now! Babylonians, I throw your god to the ground! He has rendered you traitors; he wished to take you from my power. Your god has fallen, oh foolish Hebrews, fighting against me. Hark to my words...There is only one god... your King!).

He declares himself the supreme divinity and orders the Israelites to prostrate themselves and worship him like a god: "Il volto a terra omai chinate! me nume, me adorate! [...] Non son più re, son Dio!” (Now bow down your faces to the ground! Worship me - me, God! [...] I am king no more, I am God!). The vindictive God punishes him, striking his crown with a bolt of lightning. The Babylonian king appears to be suddenly confused and worried for the first time; his thinking ability and his thoughts' content appear altered all of a sudden. The librettist also reported visual and tactile hallucination, and his emotionality is weak to the point of tears:

Chi mi toglie il regio scettro? Qual m'incalza orrendo spettro! Chi pe'l crine, ohimè, m'afferra? Chi mi stringe? Chi m'atterra? [...] Ah fantasmi ho sol presenti... hanno acciar di fiamme ardenti! E di sangue il ciel vermiglio sul mio capo si versò! Ah! Perché, perché sul ciglio una lagrima spuntò?

(Who is it that takes my royal sceptre from me? What horrid spectre is pursuing me? Who seizes me, alack, by the hair? Who is crushing me?... Who lays me low? [...] I am surrounded by phantoms...they are having flaming swords of fire! And the blood-red sky has fallen upon my head! Why, oh why did a tear start from my eye?).

Finally, he loses consciousness, ending the scene: "Chi mi regge? Io manco!" ("Who will support me?... I am fainting...”). The crown, fallen from Nabucco's head, is picked up by Abigaille, who pronounces herself ruler of the Babylonians.

In scene 2 of Act Three, Nabucco reappears still "out of his mind". Unkempt beard and ragged vestiges, his spatial orientation floats: "Ove condur mi vuoi? [...] Lascia, ben io or troverò mio seggio" (Where would you lead me? [...] Let go of me... I will find my seat myself). $\mathrm{He}$ seems to be confused enough not to recognize Abigaille: "Chi è costei? Oh qual Baldanza! ... Donna, chi sei?" ("Who is this woman? Oh, what effrontery! [....] Woman, who are you?"); he is manipulated by Abigaille in sentencing all the Israelites to death, including Nabucco's other daughter Fenena, who has converted to Judaism. In this way, Abigaille would eliminate her potential rival for the Assyrian throne. Suddenly, Nabucco recovers his previous awareness and sees his own mistake ("Oh!... ma Fenena?", "Oh!... But what of Fenena?"). He tells Abigaille that he is not actually her father but she was a slave ("Pròstrati, o schiava, al tuo signor!....", "Bow low, slave, before your lord!”), and even admit to himself to have been delirious ("Deh perdona, deh perdona ad un padre che delira!", “Oh, forgive, oh, forgive a father who is delirious!"). Nabucco pleads for the life of his true daughter (Fenena), but Abigaille is unmoved.

Actually, this moment of lucidity is brief and temporary. When he wakes up from a "deep drowsiness" in Act Four, he has already forgotten about the recent happen- 
ings and is surprised to see his legitimate daughter Fenena in chains ("Ohimè!... traveggo? Perché le mani di catene ha cinte?... Piange!"; "Am I dreaming? Why are her hands bound in chains?...She is weeping!") and notices that he is being held captive ("Ah, prigioniero io sono!", "Oh! I am a prisoner!"). It may be supposed that his level of consciousness has risen. Nabucco prays to the God of Israelites, asking for forgiveness, and promises to rebuild the temple in Jerusalem and convert himself to Judaism if his prayers are answered. Miraculously, his reason is immediately restored: "La mente or più non è smarrita! [...] S'apre alla mente il giorno" ("My mind is no longer deranged! [...] Day opens to my mind"). He reconquers his throne from his illegitimate daughter Abigaille, who confesses her crimes and dies, poisoning herself. Without ever again showing sign of psychic decompensation or altered consciousness, Nabucco tells the Israelites to return to their native land and rebuild their Temple, declaring that he himself now serves the God of the Israelites.

\section{Discussion}

\section{Nabucco's Delirium}

In Verdi's Nabucco, the Assyrian king's attention, awareness, perception and sensitivity, inventive contents, memory and consciousness all appear to be impaired and fluctuate in the course of the events. These features may lead us to hypothesize that he suffered from delirium. Delirium is a syndrome encompassing an array of neuropsychiatric symptoms, which represents a disarrangement of the cerebral function in response to one or more pathophysiological stressors [6]. According to the Diagnostic and Statistical Manual of Mental Disorders-5th edition (DSM-5), key diagnostic features of delirium include an acute onset and fluctuating course of symptoms, inattention, impaired consciousness and disturbance of cognition (e.g., disorientation, memory impairment, language changes) [6]. Occasionally, disturbance in perceptual disturbances (hallucinations or illusions), delusions, psychomotor disturbance (hypoactivity or hyperactivity), inappropriate behavior and emotional lability are part of delirium [7]. Delirium is usually the direct physiological consequence of another medical condition, substance intoxication or withdrawal (i.e., due to drug abuse or medication), exposure to a toxin, or due to multiple etiologies. It may present itself in hyperactive, hypoactive or mixed forms. In its hyperactive form, it manifests as severe confusion and disorientation; developing with a relatively rapid onset and fluctuating in intensity. In its hypoactive form, it manifests as an equally sudden withdrawal from interaction with the outside world. Although these 2 forms are distinctive clinically, patients can wax and wane between them during the course of a day or the course of the disorder (mixed type) [8]. Interestingly, delirium may be a harbinger of future negative outcomes including death and cognitive impairment $[9,10]$.

In Nabucco's case, the most probable underlying organic cause would be the lightning that hit the crown, and possibly the king's head. As a matter of fact, the disturbances could not be better explained by another pre-existing condition, thus making delirium a very likely hypothesis. The electrical nature of the triggering factor leaves room for further speculations, such as diagnosis of "excited delirium". This syndrome is not mentioned in the DSM-5, but it is recognized by the American College of Emergency Physicians and by the National Association of Medical Examiners. Excited delirium manifests itself as a combination of delirium, psychomotor agitation, anxiety, hallucinations, speech disturbances, disorientation, violent and bizarre behavior, insensitivity to pain, elevated body temperature, increased strength and frequently sudden death. The most frequent causes of excited delirium are Taser-related electrical shocks [11]. Admittedly, some of the typical signs and symptoms, such as elevated body temperature, insensitivity to pain, violence or increased strength, cannot be found in the opera.

Another delirium-associated syndrome worth citing is Bell's mania [12]. It was first described in 1849, a little after Verdi's Nabucco. Luther V. Bell (1806-1862) was one of the founders of the Association of Medical Superintendents of American Institutions for the Insane in 1844, original nucleus of the American Psychiatric Association. Bell's mania (or mania with delirium) is an acute neurobehavioral syndrome of unknown etiology that is characterized by the rapid onset of grandiosity, psychomotor excitement, emotional lability, psychosis and sleep disruption consistent with mania, coupled with alterations in sensorium and disorientation. Catatonia is also a common attribute of the syndrome, but is nowhere to be found in Nabucco [13]. Some other differential diagnoses not caused by an organic trauma and therefore excluded from our most probable causes are psychotic, affective and acute stress disorders.

\section{Nabucco and the Development of Psychiatry}

In addition to the differential hypotheses regarding the diagnosis of Nabucco's disorder, it may be of interest to underline how this opera could provide informa- 
tion on the state of knowledge on neuropsychiatric diseases in the first part of the nineteenth century. A key point is the differentiation of Nabucco's sudden madness from the episode described in the Bible. According to Daniel 4:33, King Nabuchodonosor "was driven away from other humans and ate grass like cattle. Dew from heaven washed his body until he grew hair like eagles' feathers and claws like a bird". This has been referred to as a lycanthropy, or more precisely boanthropy; that is, a psychological disorder in which a human believes himself or herself to be a bovine [5]. In the psychiatric literature, lycanthropy is understood as an unusual belief or delusion to be transformed into an animal or into behaviors or feelings suggestive of such a belief [14]. The Swiss psychiatrist Jung [15] (18751961) defined "Nebuchadnezzar [as] a complete regressive degeneration of a man who has overreached himself". What is the origin of these differences between Verdi's Nabucco and the Bible? Verdi often deviated from the original text and usually had passionate discussions with his librettists on this issue; but this is even more shocking, when considering the biblical origin of the story. The answer to this question can be found in the original drama by Anicet-Bourgeois and Cornue, which the libretto by Solera was based on. At the end of Act Three of the French drama, the origin of transitory altered mental state of Nabuchodonosor is similarly explained by lightning (foudre in French) that strikes the king and breaks his forehead ("et le coup m'a brisé le front") after his blasphemous statement ("Je suis Dieu"). As it is in the opera, the king starts to suffer from hallucinations:

Sauvez-moi!... défendez-moi!...ne voyez-vous donc pas ce fantôme terrible qui se dresse...et qui s'avance...il me saisit...il me renverse !... Ah! sa main, sa main de feu broie mon front (Save me!... Defend me!... Do you not see that terrible ghost that stands... and that juts... he grabbed me... it amazes me!...Ah his hand, his hand of fire grinds my forehead).

The biblical story of the madness of the king of Babylon was, therefore, originally modified by Anicet-Bourgeois and Cornue in their drama, and in turn inspired Solera's libretto and Verdi's opera. The French writers were most likely influenced by the medical knowledge of the first part of the nineteenth century, when neuropsychiatry was emerging as an autonomous discipline, thanks to the contributions of Philippe Pinel (1745-1826) and Jean-Étienne Dominique Esquirol (1772-1840) in France. The medicalization of madness, together with a general humanization of life conditions of those affected by mental disorders, were the main characteristics of the French psychi- atric reform [16]. The influence of French culture and experience on Italian psychiatry was very important throughout the first part of the nineteenth century. The first true Italian lunatic asylum was opened in 1813, in Aversa (Naples) under the enlightened government of Gioacchino Murat, Napoleon's brother-in-law [16]. The theories formulated by Pinel and Esquirol mainly influenced the alienists of the northern Italy, such as Cesare Vigna (1819-1892) in Venice and Andrea Verga (18111895) in Milan; both of them were known to Giuseppe Verdi. Vigna was indeed a close friend of Verdi and his second wife, the soprano Giuseppina Strepponi (18151897) [17], while the Italian composer had the opportunity to meet Verga and to discuss with him in the literary salon held by Giuseppina Morosini (1824-1909) in 1880s. The influence of Pinel was crucial in the development of "moral treatment" among Italian alienists. Madness was considered as a disease of the brain and the nervous system, but it was considered curable by the moral means of the asylum, based on a re-education of the patient in hygienic and moral principles: clean air, personal hygiene and correct diet, reinforced by work, discipline and isolation [16]. For example, Vigna, director of the psychiatric hospital on the Venetian island of San Clement, investigated the positive effects of music on his patients, who could freely listen to music in a dedicated room in the hospital [17]. Music was then considered a tool to soothe the mind of psychiatric patients and so to contribute to their "moral re-education."

In this context, mental symptoms and signs were better known and investigated, as demonstrated by the aforementioned studies of Luther Bell on delirium. In particular, delirium had been identified in the previous century as an autonomous condition by different authors, who differentiated it from madness [18]. In his "Zoonomia" (1794), Erasmus Darwin [19] (1731-1802) stated:

Madness is distinguishable from delirium, as in the latter the patient knows not the place where he resides, nor the persons of his friends or attendants, nor is conscious of any external objects, except when spoken to with a louder voice, or stimulated with unusual force, and even then he soon relapses into a state of inattention to everything about him [19].

This definition of delirium is well reflected both in the French drama and in the Italian opera. It is curious that both the French authors and Verdi's libretist used the adjective "delirious" to identify the altered state of the king of Babylon, leading to speculation that the term was well used in both languages. Indeed, during the nineteenth century, "delirium" replaced obsolete terms such as phrenitis, phrensy, phrenesis, lethargy and para- 
phrensy or paraphrenesis that gradually disappeared from both medical language [18] and common language. To support the role of medical evolution in the change of vocabulary, it should be considered how the Italian term "delirio" is also found in other Verdi's operas subsequent to Nabucco. In "Don Carlos" (1867), the protagonist is defined as "deliro" (Act Three, scene 1 ), as a synonym of fool, while at the end of the Act One of "La Traviata" (1853) Violetta claimed "Follie! follie! Delirio vano è questo!" ("Folly! All is folly! This is mad delirium!"). In this latter opera, the final scene of the death of Violetta by tuberculosis could be another example of delirium. Indeed, before death claims her, energy and exuberant joy of life return, all sorrow and suffering seem to have left her in a kind of "terminal delirium" ("È strano! Cessarono gli spasimi del dolore. In me rinasce - m'agita insolito vigor! $\mathrm{Ah}$ ! $\mathrm{ma}$ io ritorno a viver! Oh gioia!", "How strange! The spasms of pain have ceased: a strange vigor has brought me to life! Ah! I shall live. Oh, joy!”).

\section{Nabucco and Verdi's Personal Life}

Even though Solera's libretto and French drama are important to understand the potential medical influences in the opera, the musical score by Giuseppe Verdi may hide something else. In Nabucco's delirium scenes, the music of the Italian composer helps the listeners to identify with the anguishes and sufferings of the mentally ill. The strength of these scenes is further enhanced by the skills of the baritone who plays the king. A possible explanation of Verdi's ability to bring truth to the pain of Nabucco may be found in the biography of the artist himself. The early years of his career were marked by a series of sorrowful events, including the death of 2 of his children in 1838 and 1839 , and that of his beloved wife Margherita, only 26 years old, in 1840. It may not be coincidental that his second opera, the melodramma gioioso "Un giorno di regno" (1840), was a complete fiasco. Starting in those years and continuing for the rest of his life, the composer suffered from frequent and recurring depressive episodes, and only at the end of 1840s he turned to the aforementioned alienist, Cesare Vigna [17]. During these troubling times, Verdi even thought of quitting composing. When Bartolomeo Merelli (1794-1879), theatre manager of La Scala, asked him to score the "Nabucco," Verdi immediately appreciated Solera's libretto, but it was only after several months that he was convinced to accept the job. "Nabucco" premiered at the La Scala theatre in Milan in 1842,2 years after the tragic events in his personal life. Therefore, one could speculate that the depressive episode greatly affected Verdi during and after the composition of Nabucco, and that the angst, sadness and emptiness that the composer experienced could have been transferred to Nabucco's pain when he discovers that his daughter is sentenced to death.

\section{Conclusions}

"Nabucco" provides a clear example of how operas could be used as a valuable tool to investigate the state of knowledge of neuropsychiatric disease in the Romantic era $[1-3,20]$. Opera was at the height of popularity during this time, with an audience mostly composed of the upper-class and the well-educated, who considered it to be unworthy of attendance if it were not grandiose and spectacular [2]. For this reason, these works can be considered to be a link between the popular and the intellectual world, including scientists and physicians. "Nabucco" by Giuseppe Verdi confirms again that Romantic operas can still serve as "valuable resources for understanding mental (and physical) disorders during times past, especially as conveyed from and to non-physicians [3]."

\section{Disclosure Statement}

The authors certify that there is no actual or potential conflict of interest in relation to this article.

\section{References}

1 Riva MA, Sironi VA, Tremolizzo L, Lombardi C, De Vito G, Ferrarese C, Cesana G: Sleepwalking in Italian operas: a window on popular and scientific knowledge on sleep disorders in the 19th century. Eur Neurol 2010;63: 116-121.

2 Finger S, Sironi VA, Riva MA: Somnambulism in Verdi's Macbeth and Bellini's La Son- nambula: opera, sleepwalking, and medicine. Prog Brain Res 2015;216:357-388.

3 Riva MA, Mazzocchi C, Cesana G, Finger S: "Il Sonnambulo" by Michele Carafa: a forgotten romantic opera with sleepwalking. Eur Neurol 2016;76:210-215.

4 Riva MA, Bellani I, Turato M, Cesana G: Physicians and alternative medicines in "The Bar- ber of Seville" by Gioachino Rossini: a bicentennial debate. Eur J Intern Med 2015;26:757758.

5 Summers M: The Werewolf in Lore and Legend. New York, Dover Publication, 2003.

6 American Psychiatric Association: Diagnostic and Statistical Manual of Mental Disorders, ed 5. Washington, DC, APA, 2013. 
7 Inouye SK, Westendorp RG, Saczynski JS: Delirium in elderly people. Lancet 2014;383: 911-922.

8 Bellelli G, Mazzola P, Morandi A: Delirium as a marker of vulnerability in the elderly. Geriatric Care 2015;1:1.

9 Bellelli G, Mazzola P, Morandi A, Bruni A, Carnevali L, Corsi M, Zatti G, Zambon A, Corrao G, Olofsson B, Gustafson Y, Annoni G: Duration of postoperative delirium is an independent predictor of 6-month mortality in older adults after hip fracture. J Am Geriatr Soc 2014;62:1335-1340.

10 Davis DH, Muniz Terrera G, Keage H, Rahkonen T, Oinas M, Matthews FE, Cunningham C, Polvikoski T, Sulkava R, MacLullich AM, Brayne C: Delirium is a strong risk factor for dementia in the oldest-old: a population-based cohort study. Brain 2012;135(pt 9):2809-2816.
11 Kraines SH: Bell's mania. Am J Psych 1934;91: 29-40.

12 Cengiz SL, Baysefer A: A unique case of delirium resulting from electrical accident-induced spinal trauma. Prim Care Companion J Clin Psychiatry 2007;9:319.

13 Bobo WV, Murphy MJ, Heckers SH: Recurring episodes of Bell's mania after cerebrovascular accident. Psychosomatics 2009;50:285288.

14 Bou Khalil R, Dahdah P, Richa S, Kahn DA: Lycanthropy as a culture-bound syndrome: a case report and review of the literature. J Psychiatr Pract 2012;18:51-54.

15 Jung CG: The Symbolic Life: Miscellaneous Writings (Collected Works of C.G. Jung). Princeton, Princeton University Press, 1977, vol. $18, \mathrm{p} 110$
16 Tagliavini A: Aspects of history of psychiatry $\mathrm{n}$ Italy in the second half of the nineteenth century; in Bynum WE, Porter R, Shepherd M (eds): The Anatomy of Madness: Essays in the History of Psychiatry. London, Tavistock, 1985, vol. 2, pp 175-196.

17 Riva MA, Lorusso L, Sironi VA: Cesare Vigna (1819-1892). J Neurol 2014;261:449450

18 Adamis D, Treloar A, Martin FC, Macdonald AJ: A brief review of the history of delirium as a mental disorder. Hist Psychiatry 2007;18(72 pt 4):459-469.

19 Darwin E: Zoonomia or the Laws of Organic Life. Ann Arbor, University of Michigan Library, 2007.

20 Lorusso L, Franchini AF, Porro A: Opera and neuroscience. Prog Brain Res 2015;216:389409. 